\title{
Demographics of Educational Funds to Support Learning in Era of he Industrial Revolution
}

\author{
Hilma Harmen ${ }^{1}$, Rosmala Dewi ${ }^{2}$, Muhammad Bukhori Dalimunthe ${ }^{3}$, Fitri Yani \\ Panggabean $^{4}$, Raudah Zaimah Dalimunthe ${ }^{5}$, Vina Budiarti Mustika Sari ${ }^{6}$, Lokot Muda \\ Harahap $^{7}$, Rangga Restu Prayogo ${ }^{8}$ \\ ${ }^{1}$ Department of Management, Universitas Negeri Medan, Medan, Indonesia, ${ }^{2}$ Department of \\ Guidance and Counseling, Universitas Negeri Medan, Medan, Indonesia, ${ }^{3}$ Department of Economic \\ Education, Universitas Negeri Medan, Medan, Indonesia, ${ }^{4}$ Departement of Accounting,Universitas \\ Pembangunan Panca Budi, Medan, Indonesia, ${ }^{5}$ Department of Guidance and Counseling, Universitas \\ Sultan Ageng Tirtayasa, Banten, Indonesia, ${ }^{6}$ Department of Economic Education, IKIP Widya Darma, \\ Surabaya, Indonesia, ${ }^{7}$ Department of Management, Universitas Negeri Medan, Medan, Indonesia, \\ ${ }^{8}$ Department of Entrepreneurship, Universitas Negeri Medan, Medan, Indonesia \\ *daliori86@unimed.ac.id
}

\begin{abstract}
Education funding in Indonesia for primary education is poured into the School Operational Assistance program (SOA), especially in public schools. Since the beginning of the distribution of these funds until now has improved the financing components that can be spent through SOA funds. This paper aims to present the demographic part of the funding for education funds through the SOA program to support learning in the era of the industrial revolution. The research data is secondary in the form of the distribution of SOA funds from 2013 to 2019 obtained from the website of the Ministry of Education and Culture. The object of research is 382 public elementary schools in Medan. Data analysis used descriptive statistics combined with a qualitative narrative of the funding component of the SOA funds allocated by the School SOA Team for school operational activities based on the Minister of Education and Culture Regulations in force at that time. The top three dominant financing components were spend, namely; 1) library development; 2) payment of honorariums; and 3) student learning and extracurricular activities, respectively. Once the amount of funding allocated for library development should be highlighted more seriously by the School SOA Team, teachers, and school committees. Further review of library development is needed based on manual or automation. Proper distribution of SOA funds is more dominant in digital learning so that teachers and students are ready to face technological acceleration.
\end{abstract}

Keywords: demographics; school operational assistance funds

\section{Introduction}

The School Operational Assistance (SOA) program, which began in 2005, has played a significant role in accelerating the 9 -year compulsory education program mandated by Law number 20 of 2003 [1]. SOA is a government program that provides funding for primary schools' operational costs as a compulsory education program. 
The SOA program's goal is to help the community in financing education to complete a quality 9-year compulsory primary education. Then it is expected to accelerate the achievement of minimum service standards to students at school. SOA program targets are primary schools, secondary schools, and senior high schools with public or private status. The number of students determines the amount of SOA funds received by schools. SOA funds increase every year to adjust the government budget and meet the needs of educational services for students.

In implementing SOA fund distribution, cooperation, and coordination of SOA fund managers in schools must be harmonious. The principal, as the person in charge, must work together with other members. The accuracy of SOA fund financial reporting completion is the dominant indicator of SOA fund manager performance [2]. Excellent performance becomes a monitoring and evaluation tool used as a measure of success and determination of SOA fund allocation in the following year. To support this performance, planning for the use of SOA funds should pay attention to the principles of effective and efficient.

The presence of SOA funds is very beneficial for student learning activities, so the financing component that includes learning activities deserves more attention. Also, students in primary education must learn about the dangers of joint diseases, such as drugs, so they need to build their resilience. Optimizing the role of education in the use of technology helps strengthen students' self-resilience from the dangers of social ills [3] [4]. Other activities that can carry out take the form of programs to improve teachers' pedagogical and professional competence. Teacher competency improvement allocated to the funding component of SOA funds and in line with the mandate of the law [1] set forth in the Training Professional Teacher (TPT) program. Teachers should provide with training before participating in the TPT program, so they can adapt well when attending the program. Previous research revealed that teachers' pedagogical and professional competencies are highly relevant to TPT programs' performance testing [5].

There has been a lot of research that discusses SOA programs or funds [6] [7] [8], but there is no detailed mining of detailed information about the demographics and dominance of the funding components of SOA funds. This paper provides this information comprehensively and integrated with applicable regulations. The regulations for implementing the SOA program, which always changes each year, are undoubtedly interesting discussions to study. What happened to the implementation of the SOA program? It is a question that is still interesting to explore further. With the demographics of education funds, it was expected to become fundamental research to answer these questions. This paper aims to provide demographic information on the funding component of education funding through the SOA program in primary and secondary schools in Medan.

\section{Methodology}

The study uses a quantitative approach with descriptive technical analysis combined with the support of qualitative narratives based on the rules that apply to the implementation of the SOA program. The object of research is public elementary schools located in Medan, which amounted to 382 schools. The research data were secondary data from the distribution of SOA funds from 2013 to 2019. Secondary data collected from the official website of the Ministry of Education and Culture of the Republic of Indonesia. Analysis of the data presented 
comprehensively describes the demographics of education funds and improvements to the regulations that apply to SOA funds management each year.

\section{Result and Discussion}

\section{A. Result}

Based on research data obtained information on the amount of SOA funds from 2013 to 2019 amounting to IDR 12,348,473,547; IDR 1,525,386,474; IDR 28,663,410,687; IDR 69,849,269,825; IDR 66,973,995,535; IDR 25,897,581,677; IDR 84,326,109,418, respectively. The distribution of SOA funds in 2013 experienced a very significant increase in the number of funds up to 2016 of $82.32 \%$ but decreased to $69.71 \%$ over the next two years, and drastically increased again in 2019 (see Figure 1). Changes in the amount of SOA funds disbursed each year are not only based on the number of students in each school but also very much depends on state finances and political conditions. So that stable economic and political conditions are very meaningful for determining the allocation of SOA funds every year.

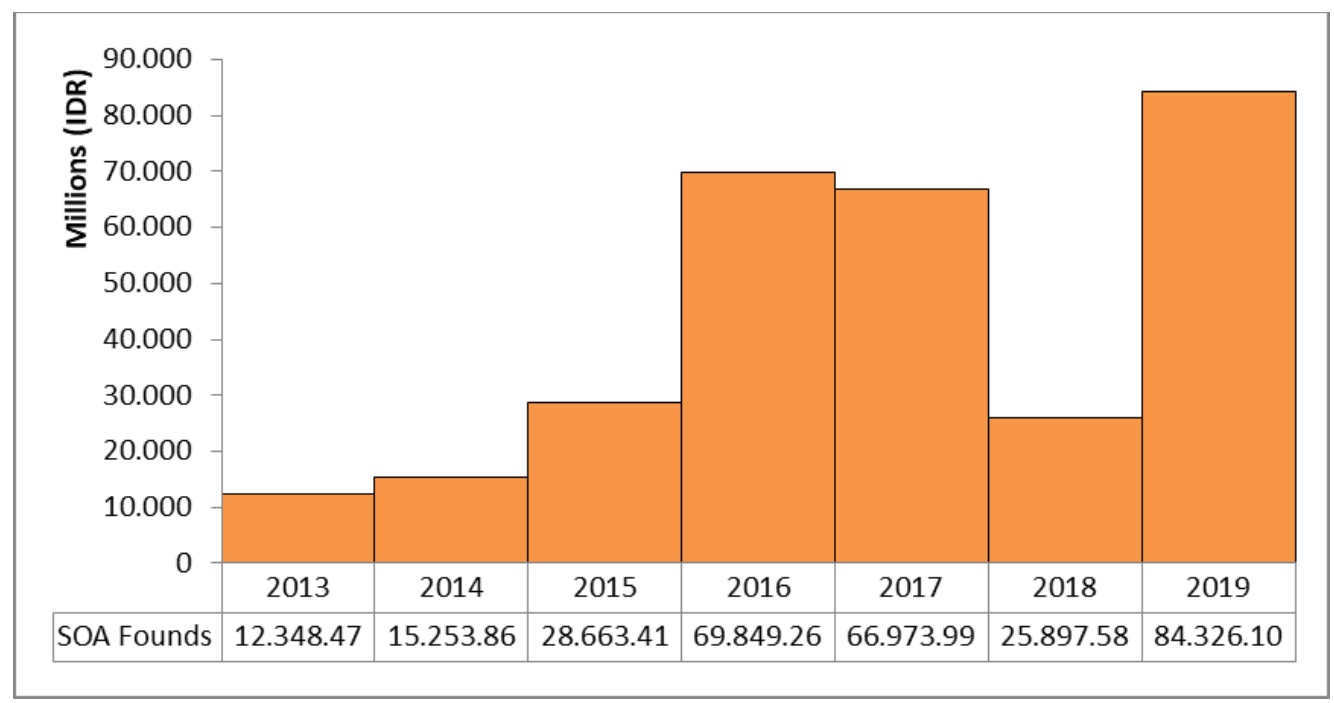

Figure. 1. Amount of School Operational Assistance Funds from 2013 to 2019

Information obtained from Table 1 shows that the distribution of SOA fund financing components is dominated by components, in 2013 - 1) student learning and extracurricular activities $(22.88 \%), 2)$ payment of honorarium $(18.98 \%), 3)$ library development $(12.64 \%)$; 2014 - 1) payment of honorarium $(21.42 \%), 2)$ student learning and extracurricular activities $(20.67 \%), 3)$ library development $(12.65 \%) ; 2015$ - 1) student learning and extracurricular activities $(18.67 \%), 2)$ payment of honorarium (17.64\%), 3) library development (16.91\%); 2016 - 1) payment of honorarium $(19.41 \%), 2$ ) library development $(19.24), 3)$ student learning and extracurricular activities $(16.44 \%) ; 2017$ - 1) library development $(19.46 \%), 2)$ payment of honorarium (16.88\%), 3) school management (13.57\%); 2018 - 1) library development $(20.54 \%), 2)$ payment of honorarium $(15.60 \%), 3)$ school management $(14.73 \%) ; 2019-1)$ library development $(21.30 \%), 2)$ school management $(16.16 \%), 3)$ payment of honorarium $(15.90 \%)$. 
Table 1. Demography of School Operational Assitance Funds Components (Millions, Idr)

\begin{tabular}{|c|c|c|c|c|c|c|c|c|}
\hline No & Components & 2013 & 2014 & 2015 & 2016 & 2017 & 2018 & 2019 \\
\hline 1 & Library development & 1,561 & 1,930 & 4,846 & 13,436 & 13,035 & 5,319 & 17,963 \\
\hline 2 & New student admission activities & 88 & 111 & 267 & 516 & 383 & 252 & 881 \\
\hline 3 & $\begin{array}{l}\text { Students learning and extra-curricular } \\
\text { activities }\end{array}$ & 2,825 & 3,152 & 5,351 & 11,486 & 8,778 & 2,574 & 11,873 \\
\hline 4 & Test and exams activities & 1,320 & 1,708 & 3,399 & 7,396 & & & \\
\hline 5 & Purchase of consumables & 1,180 & 1,636 & 3,334 & 8,762 & & & \\
\hline 6 & $\begin{array}{l}\text { Electricity/water/telephone payments } \\
\text { and services }\end{array}$ & 373 & 580 & 1,088 & 2,373 & 3,482 & 1,880 & 3,076 \\
\hline 7 & $\begin{array}{l}\text { Maintenance and repair of school } \\
\text { facilities and infrastructure }\end{array}$ & 1,068 & 1,090 & 2,254 & 4,600 & 5,960 & 1,905 & 7,191 \\
\hline 8 & $\begin{array}{l}\text { Payment of honorarium for teachers } \\
\text { and staff honorary }\end{array}$ & 2,343 & 3,267 & 5,056 & 13,556 & 11,302 & 4,040 & 13,405 \\
\hline 9 & Teacher professional development & 718 & 744 & 1,200 & 3,075 & 4,133 & 1,791 & 3,227 \\
\hline 10 & Help poor students & 10 & 14 & 41 & 239 & & & \\
\hline 11 & SOA management financing & 222 & 310 & 512 & 1,377 & & & \\
\hline 12 & Purchase a computer & 158 & 175 & 310 & 694 & & & \\
\hline 13 & Other costs & 476 & 529 & 999 & 2,333 & 1,562 & 663 & \\
\hline 14 & Learning evaluation activities & & & & & 7,652 & 3,008 & 11,411 \\
\hline 15 & School management & & & & & 9,090 & 3,815 & 13,629 \\
\hline \multirow[t]{2}{*}{16} & $\begin{array}{l}\text { Purchase/maintenance of multi-media } \\
\text { learning tools }\end{array}$ & & & & & 1,591 & 645 & 1,665 \\
\hline & Total & $\begin{array}{l}12,34 \\
8\end{array}$ & 15,253 & 28,663 & 69,849 & 66,973 & 25,897 & 84,326 \\
\hline
\end{tabular}

source: https://bos.kemdikbud.go.id/

Components dominate the overall demographic component of SOA fund financing for seven years: 1) library development; 2) payment of honorariums, and 3) student learning and extracurricular activities. SOA fund managers at schools focus primarily on increasing literacy materials in libraries to improve student literacy skills. Furthermore, the allocation of SOA funds for honorarium payments ranks second, giving a signal that teachers' welfare is still extensive depending on SOA funds, mainly intended for teachers and employees with honorary status who work in public elementary schools. It indicates the role of teachers and honorary staff vital for the delivery of primary education in Medan. The third component is the use of SOA funds in the learning activities and extracurricular activities of students. Student learning and extracurricular activities should be a significant concern by SOA fund managers because they should be the main target of schools to explore knowledge and skills from the elementary education stage so that they can become necessary raw materials for students to continue their education a higher level.

More detailed demographics of SOA funds presented each component and distribution of SOA funds every quarter can be seen in Figure 2, obtained information that SOA fund managers oriented towards channeling SOA funds every quarter on library development (point 1) with an average value of $0.21(21.30 \%)$ of SOA funds for seven years. 


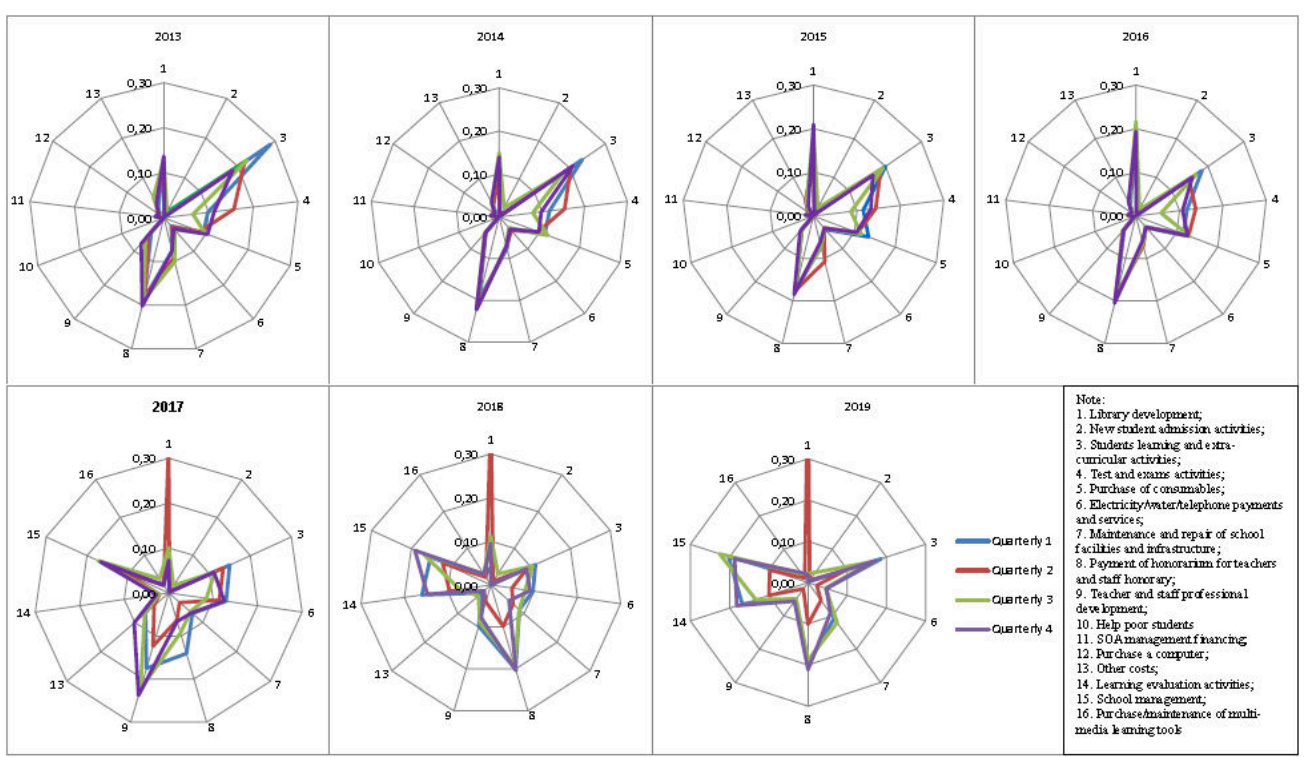

Figure 2. Demographics of School Operational Assistance Fund Components from 2013 to 2019 per Quarterly

\section{B. Discussion}

This section will describe the demographic management of SOA funds carried out by the school annually.

\section{SOA Funds Demographics in 2013}

Distribution and reporting of SOA funds in 2013 were managed by Regulation of Minister of Education and Culture Number 76 of 2012 on Technical Guidelines for the Use and Accountability of School Operational Assistance Funds for the 2013 Budget Year [9]. The SOA program manager at the school level is called the School SOA Management Team which consists of 1) the person in charge, namely the school principal; and 2) members comprised of SOA treasurers (teachers) and representatives of students' parents. The budget value of SOA funds obtained by schools based on the number of students in 2013. The distribution of SOA funds done every quarter. Quarter I in January to March period, Quarter II in April to June period, Quarter III in July to September period, and Quarter IV in the October to December period.

The percentage demographics of SOA fund financing components in 2013 consisted of; 1) library development (12.64\%); 2) new student admission activities $(0.71 \%) ; 3$ ) learning and extracurricular activities for students $(22.88 \%) ; 4)$ test and examination activities $(10.69 \%) ; 5)$ purchase of consumables $(9.56 \%)$; 6) electricity/water/telephone payments and services $(3.03 \%) ; 7)$ maintenance and repair of school facilities and infrastructure $(8.65 \%) ; 8)$ payment of honorarium for teachers and staff honorary $(18.98 \%)$; 9) teacher professional development $(5.82 \%)$; 10) help students who are poor $(0.09 \%)$; 11) SOA management financing $(1.80 \%)$; 12) purchases a computer (1.28\%); and 13$)$ other costs $(3.86 \%)$, if all components have been 
met. The applicable regulation [9] also regulates costs that should not spend using SOA funds. The three major components of financing are; learning and extracurricular activities for students, payment of honorarium for teachers and staff with honorary status, and library development, respectively (see Figure 2).

The regulation stipulates that the use of SOA funds for payment of honorariums is a maximum of $20 \%$ of the total funds received by schools. This is sufficient to improve the welfare of teachers and honorary staff. However, it is necessary to review the limitation of payment of honorariums because the contribution of teachers and honorary staff at state primary schools is substantial towards learning activities. SOA program reporting is related to descriptive statistics of beneficiaries, distribution, absorption, utilization of funds, financial accountability, and the results of monitoring and evaluation and complaints. Reporting and financial responsibility of SOA funds start from the most basic level with a bottom-up mechanism starting from the school, district/city, provincial, and central levels. The reporting grace period at each level of the SOA Fund Management Team is submitted no later than in January of the following year. Supervision and examination of SOA funds' implementation were carried out in an attached manner in every report that done annually. And institutions that have the mandate to conduct supervision are the Finance and Development Supervisory Agency (Badan Pengawasan Keuangan dan Pembangnan - BPKP) at the request of an audit by the relevant agency.

\section{SOA Funds Demographics in 2014}

The implementation of SOA fund management activities in 2014 is Regulation of Minister of Education and Culture Regulation Number 76 of 2014 on Amendment to Regulation of Minister of Education and Culture Number 101 of 2013 on Technical Guidelines on the Use and Financial Responsibility of SOA Funds for Budget Year 2014 [10]. The regulation is an improvement on the Minister of Education and Culture Regulation [11] in the previous year.

The distribution of SOA funds in 2014 takes place every quarter. However, there are differences in the delivery of SOA funds the previous year. The difference lies in the school year, while the SOA program's implementation in 2013 applies to the calendar year. In 2014, Quarter I (period January to March) and Quarter II (period April to June) for the 2013/2014 school year, and Quarter III (period July to September) and Quarter IV (period October to December) for the 2014 / the academic year 2015 (even and odd). Primary schools and secondary schools with the status of public schools were prohibited from collecting fees to parents. Whereas for private schools, the opposite applies to meet investment costs and operational costs at school. However, primary and secondary schools (public or private) can receive donations from the community or school committee to meet the lack of expenses required by voluntary schools. The SOA program manager at the school level is called the School SOA Management Team, which consists of 1) the person in charge, namely the principal; and 2) members comprised of SOA treasurers (teachers) and representatives of students' parents.

The percentage demographics of SOA fund financing components in 2014 consisted of; 1) library development $(12.65 \%)$; 2) new student admission activities $(0.73 \%) ; 3)$ learning and extracurricular activities for students $(20.67 \%)$; 4) test and examination activities $(11.20 \%) ; 5)$ purchase of consumables $(10.73 \%) ; 6)$ electricity/water/telephone payments and services $(3.81 \%)$; 7) maintenance of school facilities and infrastructure $(7.15 \%) ; 8)$ payment of honorarium for teachers and staff honorary $(21.42 \%)$; 9) teacher professional development 
$(4.88 \%) ; 10)$ help students who are poor $(0.10 \%)$; 11) SOA management financing $(2.04 \%)$; 12) purchases a computer $(1.15 \%)$; and 13$)$ other costs $(3.47 \%)$, if all components have been met. Applicable regulations [10] also regulate costs that may not spend using SOA funds. The three major components of financing are; payment of honorarium for teachers and staff honorary, learning and extracurricular activities for students, and library development, respectively (see Figure 2).

\section{SOA Funds Demographics in 2015}

The Regulation of Minister of Education and Culture Number 161 the year 2104 on Technical Guidelines for Financial Use and Accountability of the School Operational Assistance Fund for the 2015 Budget Year [12], which clearly and completely regulates the mechanism for organizing SOA program in 2015.

There are differences in the distribution of SOA funds in 2015 with the regulations [10] of the previous year. In 2015, if primary and secondary schools had fewer than 60 students, the school would still receive SOA funding of 60 students. The threshold for the number of students and SOA funds in schools was aimed at helping schools in remote and isolated areas where they are needed in the community so that education can be well organized. The distribution of SOA funds in 2015 takes place every quarter with the same mechanism as the previous year.

The percentage demographics of SOA fund financing components in 2015 consisted of; 1) library development (16.91\%); 2) new student admission activities $(0.93 \%) ; 3$ ) learning and extracurricular activities for students $(18.67 \%)$; 4) test and examination activities $(11.86 \%) ; 5)$ purchase of consumables $(11.63 \%) ; 6)$ electricity/water/telephone payments and services $(3.80 \%)$; 7) maintenance of school facilities and infrastructure $(7.87 \%)$; 8) payment of honorarium for teachers and staff honorary $(17.64 \%)$; 9) teacher professional development $(4.19 \%) ; 10)$ help students who are poor $(0.15 \%)$; 11) SOA management financing $(1.79 \%)$; 12) purchases a computer (1.08\%); and 13$)$ other costs $(3.49 \%)$, if all components have been met. Applicable regulations [12] also regulate costs that may not spend using SOA funds. The three major components of financing are; learning and extracurricular activities for students, payment of honorarium for teachers and staff honorary, and library development, respectively (see Figure 2).

\section{SOA Funds Demographics in 2016}

Technical instructions on the use and accountability of SOA funds in 2016 was regulated by Regulation of the Minister of Education and Culture Number 16 of 2016 [13] replacing and revoking the previous regulation [14]. The regulation in 2016 is more stringent in determining the amount of SOA fund allocation for each school. This is one of the distinct and improved rules [12] for the SOA program implementation procedure from the previous year. Determination of the amount of SOA fund allocation was done in 2 stages, namely temporary allocation and final allocation. The SOA fund allocations were determined based on Primary and Secondary Education Basic Data (Data Pokok Pendidik Dasar dan Menengah Dapodikdasmen) reported by the SOA Management Team at school every quarter. Data on developments and changes in the number of students in Dapodikdasmen must be updated 
every quarter. It aims to obtain the latest information about the number of students in each school and reduce the fraudulent use of SOA funds.

The percentage demographics of SOA fund financing components in 2016 consisted of; 1) library development $(19.24 \%)$; 2) new student admission activities $(0.74 \%) ; 3)$ learning and extracurricular activities for students $(16.44 \%) ; 4)$ test and examination activities $(10.59 \%) ; 5)$ purchase of consumables $(12.55 \%)$; 6) electricity/water/telephone payments and services $(3.40 \%)$; 7) school maintenance and sanitation $(6.59 \%)$; 8) payment of honorarium for teachers and staff honorary $(19.41 \%)$; 9) teacher and employee professional development $(4.40 \%) ; 10)$ help students who are poor $(0.34 \%) ; 11)$ school management funding $(1.97 \%)$; 12) purchase a computer and maintenance $(0.99 \%)$; and 13$)$ other costs $(3.34 \%)$, if all components have been met. The applicable regulation [13] also regulates costs that should not spend using SOA funds. The three major components of financing are; payment of honorarium for teachers and staff honorary, library development, and learning and extracurricular activities for students, respectively (see Figure 2).

\section{SOA Funds Demographics in 2017}

The implementation of the SOA program in 2017 was regulated by Regulation of Minister of Education and Culture Number 26 of 2017 on Amendment to Minister of Education and Culture Regulation number 8 of 2017 on Technical Instructions for School Operational Assistance [15], which regulation has replaced the previous regulation [16]. The SOA program targets the primary and secondary schools organized by the Central Government, Regional Governments, and communities that have registered with Dapodikdasmen as recipients of SOA funds. The schools' target in channeling SOA funds frequently expanded for schools managed in addition to the Ministry of Education and Culture. It is different from the SOA program implementation in previous years.

The SOA program manager at the school level is called the School SOA Team, which consists of the person in charge (i.e., the principal). The member consists of the treasurer (teacher) and representatives of the student guardian element person in charge of data collection. The different composition of the committee from 2013 signaled the need for expanded oversight in channeling SOA funds. The updated data on the number of students as a basis for calculating the amount of SOA funds received by schools is in the spotlight of the government. It is to support the previous regulation [13], which regulates the amount of SOA fund allocation and distribution, which data on Dapodikdasmen must be updated quarterly. So it takes the party responsible for presenting school and student data.

The percentage demographics of SOA fund financing components in 2017 consist of; 1) library development (19.46\%); 2) new student admission activities $(0.57 \%) ; 3)$ learning and extracurricular activities $(13.11 \%)$; 4) electricity/water/telephone payments and services $(5.20 \%) ; 5)$ maintenance and repair of school facilities and infrastructure $(8.90 \%) ; 6)$ payment of honorarium for teachers and staff honorary $(16.88 \%) ; 7)$ teacher and staff professional development $(6.17 \%) ; 8)$ other costs $(2.33 \%)$, if all components have been met; 9) learning evaluation activities (11.43\%); 10) school management (13.57\%); and 11) purchase / maintenance of multi-media learning tools (2.38\%). The applicable regulation [15] also regulates costs that should not spend using SOA funds. The three major components of financing are; library development, payment of honorarium for teachers and honorary staff, and school management (see Figure 2). 
The SOA fund financing component in 2017 is different from previous years. Improving financing items is a strategic step by the government so that SOA program activities more funds are directed at improving the quality of student learning. However, the use of SOA funds by the school is still in routine activities, such as the implementation of the previous year's SOA program. Which component of financing library development is always a favorite activity by the School SOA Team. In comparison, the financing component of the provision of multimedia learning tools and learning evaluation activities has not been optimally allocated to SOA funds.

\section{SOA Funds Demographics in 2018}

The distribution of SOA funds in 2018 refers to Regulation of Minister of Education and Culture Number 1 of 2018 on Technical Guidelines for School Operational Assistance [17]. The mechanism of SOA program implementation in 2018 is the same as the regulation [15] of the previous year. There is no significant difference between the two rules [17] [15].

The percentage demographics of SOA fund financing components in 2018 consist of; 1) library development $(20.54 \%) ; 2)$ new student admission activities $(0.97 \%) ; 3)$ learning and extracurricular activities $(9.94 \%) ; 4)$ electricity/water/telephone payments and services $(7.26 \%) ; 5)$ maintenance and repair of school facilities and infrastructure $(7.36 \%) ; 6)$ payment of honorarium for teachers and staff honorary $(15.60 \%) ; 7)$ teacher and staff professional development $(6.92 \%) ; 8)$ other costs $(2.56 \%)$, if all components have been met; 9) learning evaluation activities (11.62\%); 10) school management (14.73\%); and 11) purchase/maintenance of multi-media learning tools (2.49\%). The applicable regulation [15] also regulates costs that should not spend using SOA funds. The three major components of financing are; library development, payment of honorarium for teachers and staff honorary, and school management, respectively. The financing component in 2018 is the same as the previous year (see Figure 2).

\section{SOA Funds Demographics in 2019}

Distribution of SOA funds in 2019 based on Regulation of Minister of Education and Culture Number 35 of 2019 on the Second Amendment to Regulation of Minister of Education and Culture Number 3 of 2019 on Technical Guidelines for Regular School Operational Assistance [18]. Interestingly, this regulation was made to perfect two regulations [19] [20] made in the same year. The regulation highlights the governance of Goods/Services Procurement Mechanisms (Pengadaan Barang/Jasa - PBJ) in schools based on effective, efficient, transparent, openness, competitive, fair, and accountable. These principles did not exist in the distribution of SOA funds in previous years.

PBJ implementers in schools are carried out by school PBJ management, consisting of the headmaster, SOA treasurers, administrative staff, teachers, and PBJ providers. School PBJ management carries out PBJ requests via online (SIPLah application) or offline to PBJ Providers, which is the mechanism for implementing PBJ through a tender process. Regulation [18] highlights the PBJ implementation process, while the distribution of SOA funds to learning activities does not receive special attention. This gives a signal that the distribution of SOA funds in PBJ activities often founded errors or fraud committed by 
managers of SOA funds at the school level. To create good governance, the PBJ implementation mechanism is supported by the SIPLah application (https://siplah.kemdikbud.go.id/), aiming to avoid fraud in SOA fund distribution.

The percentage demographics of SOA fund financing components in 2019 consist of; 1) library development $(21.30 \%) ; 2$ ) new student admission activities (1.05\%); 3) learning and extracurricular activities $(14.08 \%)$; 4) electricity/water/telephone payments and services $(3.65 \%) ; 5)$ maintenance and repair of school facilities and infrastructure $(8.53 \%)$; 6) payment of honorarium for teachers and staff honorary $(15.90 \%) ; 7)$ teacher and employee professional development (3.83\%); 8) learning evaluation activities (13.53\%); 9) school management $(16.16 \%)$; and 11$)$ purchase/maintenance of multi-media learning tools $(1.97 \%)$. The current regulation [18] also regulates costs that must not spend using SOA funds. The three major components of financing are; library development, school management, and the payment of honorarium for teachers and staff honorary, respectively (see Figure 2). The financing component in 2019 is different from the previous year, namely the absence of other cost components.

\section{Conclusion}

The regulation for the distribution of education funds in Medan has consistently improved and perfected SOA funds distribution. Every year the implementation of the SOA program is carried out based on the regulations in force in the program's fiscal year. The regulation mechanism for channeling SOA funds changes each year. It was intended to minimize the gaps in indications of potential fraudulent disbursement of SOA funds that can harm state finances.

Changes to the regulation as a result of the demographics of SOA fund financing components. So that the financing component from 2013 changed from 2019. Three components that dominated the funding carried out by the School SOA Team for seven years, namely; 1) library development $(19.15 \%)$; 2) payment of honorarium $(17.46 \%)$; and 3 ) learning and extracurricular activities for students (15.18\%). The spotlight on the SOA fund financing component is the development of a library that has been consistent for seven years, ranking the third largest of the other items.

This condition is inversely proportional to the financing component's term, which were oriented towards learning activities to prepare students for the industrial revolution era. So that the regulations [21] that currently apply, especially those regulating the implementation mechanism of PBJ to support distance learning. The education fund demographics have presented comprehensively, but they are still fundamental and not yet proportional to the school's financing component. It can be primary research to trace the governance of channeling SOA funds at the school, regional, and central government levels.

\section{Acknowledgment}

The authors acknowledge their gratefulness to Medan State University for providing financial support for applied research grants in 2020. 


\section{References}

[1] Law Number 20 of 2003 on the National Education System.

[2] Dalimunthe, M. B. Analisis Kepuasan Kerja, Kejelasan Peran, Dan Kinerja Bendahara Bantuan Operasional Sekolah Di Sekolah Dasar Negeri Kota Medan. Master's Thesis: Universitas Sumatera Utara. 2010. http://repository.usu.ac.id/handle/123456789/20521

[3] Dewi, Rosmala, et al. "Self-Resilience Model of Drug Initiation and Drug Addiction (A Structural Equation Model Approach)." Archives of Psychiatry Research, vol. 56, no. 1, 2020: 5-18. https://doi.org/10.20471/may.2020.56.01.01.

[4] Dewi, Rosmala, et al. "Self-Resilience of Students In Drug Initiations." International Journal of Scientific \& Technology Research, vol. 9, issue. 01, 2020: 2724-2729. http://www.ijstr.org/final-print/jan2020/Self-resilience-Of-Students-In-DrugInitiations.pdf

[5] Dalimunthe, M.B., et al. "Evaluation of Teacher Professional Training Program with Contextual, Input, Process, and Product (CIPP) Models.” Education, Social Sciences and Humanities in Industrial Revolution 4.0. Ed. RedWhite Press, 2019: 168-174. https://series.gci.or.id/article/213/13/icesshum-2019

[6] Rofiah, S.A., et al. "Effectiveness and Efficiency Analysis Mnagement of School Operational Assistance Funds (BOS) on Educational Institutions (Case Study on Elementary School of 3 Ngroto, Grobogan).” Journal of Management, vol. 5. No. 5, 2019.

[7] Saputra, K.A.K., et al. "Preventing Fraudulent Use of Funds Management Operational Support Education.” International Journal of Psychosocial Rehabilitation, vol. 24, no. 06, 2020.

[8] Sedan, W. "The Effectiveness Funds Program of School Operational Assistance at the Elementary School in Sumba Barat Daya District of Nusa Tenggara Timur ProvinceIndonesia." Economic and Social Development: Book of Proceedings, 2015

[9] Regulation of Minister of Education and Culture Number 76 of 2012 on Technical Guidelines for the Use and Accountability of School Operational Assistance Funds for the 2013 Budget Year.

[10] Regulation of Minister of Education and Culture Number 76 of 2014 on Amendment to Regulation of Minister of Education and Culture Number 101 of 2013 on Technical Guidelines for the Use and Financial Responsibility of School Operational Assistance Funds for the 2014 Budget Year.

[11]Regulation of Minister of Education and Culture Number 101 of 2013 on Technical Guidelines for the Use and Financial Responsibility of School Operational Assistance Funds for the 2014 Budget Year.

[12] Regulation of Minister of Education and Culture Number 161 year 2104 on Technical Guidelines for the Use and Financial Responsibility of School Operational Assistance Funds for the 2015 Budget Year.

[13] Regulation of Minister of Education and Culture Number 16 of 2016 on Amendment to Regulation of Minister of Education and Culture Number 80 of 2015 on Technical Instructions for the Use and Financial Responsibility of School Operational Assistance Funds. 
[14]Regulation of Minister of Education and Culture Number 80 of 2015 on Technical Guidelines for the Use and Financial Responsibility of School Operational Assistance Funds.

[15] Regulation of Minister of Education and Culture Number 26 of 2017 on Amendment to Regulation of Minister of Education and CultureNnumber 8 of 2017 on Technical Instructions for School Operational Assistance.

[16] Regulation of Minister of Education and Culture Number 8 of 2017 on Technical Guidelines for School Operational Assistance.

[17]Regulation of Minister of Education and Culture Number 1 of 2018 on Technical Guidelines for School Operational Assistance.

[18]Regulation of Minister of Education and Culture Number 35 of 2019 on Second Amendment to Regulation of Minister of Education and Culture Number 3 of 2019 on Technical Instructions for Regular School Operational Assistance.

[19] Regulation of Minister of Education and Culture number 3 of 2019 on Technical Guidelines for Regular School Operational Assistance.

[20] Regulation of Minister of Education and Culture Number 18 of 2019 on Amendments to Regulation of Minister of Education and Culture Number 3 of 2019 on Technical Instructions for Regular School Operational Assistance.

[21]Regulation of Minister of Education and Culture Number 19 of 2020 on Amendment to Regulation of Minister of Education and Culture Number 8 of 2020 on Technical Instructions for Regular School Operational Assistance. 